\title{
MODEL PROBLEM BASED LEARNING MENGGUNAKAN TEAM TEACHING DENGAN TEKNIK TERINTEGRASI DAN SEMI TERINTEGRASI PADA PEMBELAJARAN BAKTERIOLOGI DITINJAU DARI KEMAMPUAN BERPIKIR KRITIS DAN KEMAMPUAN VERBAL
}

\author{
Yusianti Silviani ${ }^{1}$, Suciati Sudarisman ${ }^{2}$ dan Sugiyarto ${ }^{3}$ \\ ${ }^{1}$ Akademi Analis Kesehatan Nasional \\ Surakarta, 57155, Indonesia \\ yusianti_silviani@yahoo.com \\ ${ }^{2}$ Program Studi Pendidikan Sains Pascasarjana Universitas Sebelas Maret \\ Surakarta, 57126, Indonesia \\ suciati_sudarisman@yahoo.com \\ ${ }^{3}$ Program Studi Biosains Pascasarjana Universitas Sebelas Maret \\ Surakarta, 57126, Indonesia \\ sugiyarto_ys@yahoo.com
}

\begin{abstract}
Abstrak
Tujuan dari penelitian ini adalah untuk mengetahui pengaruh Problem Based Learning (PBL) menggunakan team teaching dengan teknik terintegrasi dan semi terintegrasi, kemampuan berpikir kritis, kemampuan verbal serta interaksinya terhadap prestasi belajar kognitif, afektif, dan psikomotor. Metode yang digunakan adalah eksperimen, dilaksanakan pada Januari 2012 sampai Desember 2012. Populasinya adalah semua mahasiswa Tingkat II Semester III Akademi Analis Kesehatan Nasional Surakarta Tahun Akademik 2012/2013. Teknik sampling yang digunakan adalah sampling jenuh yang terdiri dari 2 kelas yaitu: 2A1 dan 2A2. Kelas 2A1 diberi pembelajaran team teaching teknik semi terintegrasi, sedangkan 2A2 dengan team teaching teknik terintegrasi. Teknik pengumpulan data adalah tes dan non tes. Teknik tes menggunakan soal pilihan ganda untuk kemampuan berpikir kritis, kemampuan verbal, kognitif, dan psikomotor. Teknik non tes menggunakan lembar observasi untuk afektif dan psikomotor proses, serta angket untuk afektif. Pengujian hipotesis dilakukan dengan uji alternatif ANAVA yaitu Mann-Whitney dan Kruskal-Wallis. Hasil penelitian menunjukkan bahwa: 1) ada pengaruh model PBL menggunakan team teaching teknik terintegrasi dan semi terintegrasi terhadap semua prestasi belajar; 2) ada pengaruh kemampuan berpikir kritis terhadap prestasi kognitif dan psikomotor; 3) ada pengaruh kemampuan verbal terhadap semua prestasi belajar; 4) ada pengaruh interaksi teknik pembelajaran dengan kemampuan berpikir kritis terhadap semua prestasi belajar; 5) ada pengaruh interaksi teknik pembelajaran dengan kemampuan verbal terhadap semua prestasi belajar; 6) ada pengaruh interaksi kemampuan berpikir kritis dengan kemampuan verbal terhadap semua prestasi belajar; 7) ada pengaruh interaksi teknik, kemampuan berpikir kritis dan kemampuan verbal terhadap semua prestasi belajar.
\end{abstract}

Kata Kunci: Problem Based Learning, team teaching, kemampuan berpikir kritis, kemampuan verbal.

\section{Pendahuluan}

Perguruan Tinggi di bidang kesehatan (dalam hal ini Akademi Analis Kesehatan) berperan penting dalam menghasilkan tenaga analis yang kompeten dan berkualitas dengan cara membekali teori dan praktik meliputi kognitif, psikomotor dan afektif melalui beberapa mata kuliah seperti: Bakteriologi, Parasitologi, Hematologi, Immunoserologi, dan lain sebagainya. Melalui materi perkuliahan tersebut, diharapkan mahasiswa mampu berpikir tingkat tinggi 
ISSN: 2252-7893, Vol 2, No 12013 (hal 88-99)

http://jurnal.fkip.uns.ac.id/index.php/sains

seperti berpikir kritis, berpikir analitis, dan lain sebagainya.

Kompetensi psikomotor seorang tenaga analis sesuai Kurikulum Berbasis Kompetensi dari Pusat Pendidikan Tenaga Kesehatan Badan Pengembangan dan Pemberdayaan Sumber Daya Masyarakat Kesehatan (Kementrian Kesehatan Republik Indonesia, 2010) adalah: 1) mempersiapkan proses teknis operasional di laboratorium kesehatan; 2) mengembangkan prosedur untuk mengambil dan memproses spesimen; 3) melaksanakan uji analitik terhadap reagen dan spesimen; 4) mengoperasikan dan memelihara peralatan/instrumen laboratorium; 5) menjaga kesehatan dan keselamatan kerja di laboratorium dan lingkungannya; 6) mengevaluasi data laboratorium untuk memastikan akurasi dan prosedur pengendalian mutu, serta mengembangkan pemecahan masalah yang berkaitan dengan data hasil uji; 7) membantu klinis dalam pemanfaatan data laboratorium secara efektif dan efisien untuk menginterprestasikan hasil uji laboratorium; 8) merencanakan, mengatur, melaksanakan dan mengevaluasi kegiatan laboratorium; 9) membimbing dan membina tenaga kesehatan lain dalam bidang teknik ke laboratorium; 10) melaksanakan penelitian dalam bidang laboratorium kesehatan; 11) memberikan penyuluhan kepada masyarakat yang berkaitan dengan laboratorium kesehatan. Selain kompetensi kognitif dan psikomotor, tenaga analis kesehatan juga memerlukan sikap jujur, teliti, disiplin, bertanggung jawab, dapat diandalkan dan mampu bekerjasama dalam tim. Tenaga analis kesehatan yang kompeten diharapkan akan memiliki daya saing tinggi baik di tingkat nasional maupun internasional.

Profil kompetensi tenaga analis kesehatan di atas relevan dengan hakikat sains yang meliputi 3 aspek yaitu: produk, proses, dan sikap. Produk belajar sains (scientific products) berupa kumpulan informasi berupa fakta, konsep, hukum, prinsip, dan teori yang dihasilkan melalui proses ilmiah yaitu pemecahan masalah.
Aktivitas dalam proses sains disebut sebagai keterampilan proses sains meliputi kegiatan: pengamatan, interferensi, prediksi, klasifikasi, menyimpulkan, dan mengkomunikasikan hasil. Sikap dalam sains adalah sikap yang berkembang setelah seseorang melakukan proses sains seperti: rasa ingin tahu, jujur, disiplin, kritis, teliti, terbuka, dll (Weno, 2008).

Materi biologi di Akademi Analis Kesehatan (AAK) khususnya mata kuliah Bakteriologi ditujukan agar mahasiswa dapat menganalisa berbagai macam bakteri yang tersebar di sekitar manusia, serta menerapkan Kesehatan dan Keselamatan Kerja (K3) dalam pelaksanaan pemeriksaan Bakteriologi. Mengacu pada tujuan mata kuliah Bakteriologi tersebut maka idealnya pembelajaran sains (khususnya biologi) di AAK idealnya dapat mengembangkan keterampilan proses sains baik keterampilan proses sains dasar dan terintegrasi (Nur, 2011).

Secara umum kompetensi tenaga kesehatan di Indonesia masih rendah. Berdasarkan data dari Pusat Dinas Kesehatan (2007) diketahui bahwa negaranegara maju seperti Amerika Serikat, Uni Eropa, negara Timur Tengah, dan Malaysia, lebih menyukai tenaga kesehatan dari Filipina dan Thailand. Hal tersebut menunjukkan bahwa kompetensi tenaga Indonesia dipandang belum mampu bersaing dengan tenaga kesehatan dari negara lain. Kualitas pembelajaran di Perguruan Tinggi (AAK) turut memberikan konstribusi terhadap rendahnya kompetensi analis kesehatan.

Pembelajaran di AAK Nasional menuntut kemampuan kognitif, afektif dan psikomotor. Hasil pengamatan menunjukkan bahwa mahasiswa AAK Nasional belum mempunyai keterampilan proses sains yang memadai terutama dalam memecahkan masalah melalui metode ilmiah. Hal ini terlihat bahwa mahasiswa masih memerlukan banyak bimbingan saat mengerjakan soal yang menuntut kemampuan berpikir tingkat tinggi,

Salah satu faktor penyebab belum memadainya kompetensi mahasiswa di AAK Nasional adalah cara dosen dalam 
ISSN: 2252-7893, Vol 2, No 12013 (hal 88-99)

http://jurnal.fkip.uns.ac.id/index.php/sains

mengajar yaitu menggunakan metode ceramah (lecturing) dengan power point, keadaan ini disebabkan oleh: 1) padatnya jadwal dosen dalam perkuliahan; 2) latar belakang keilmuan dosen bervariasi; dan 3) karakteristik materi di AAK Nasional kompleks dan abstrak. Kondisi tersebut di atas perlu diperbaiki, salah satu cara yang bisa dilakukan adalah melatihkan kemampuan memecahkan masalah melalui KPS dengan Problem Based Learning (PBL).

Model PBL adalah model pembelajaran yang berawal dari adanya masalah. Sintaks PBL adalah orientasi masalah, mengorganisasikan mahasiswa untuk belajar, membimbing pengalaman individual/kelompok, mengembangkan dan menyajikan hasil karya, menganalisis dan mengevaluasi proses pemecahan masalah. Model PBL memiliki banyak keunggulan diantaranya: 1) pembelajaran berpusat pada mahasiswa; 2) memungkinkan mahasiswa untuk melihat secara multidimensi dengan perspektif yang lebih mendalam; 3) mengembangkan keterampilan memecahkan masalah, keterampilan sosial, komunikasi dengan belajar tim, keterampilan berpikir kritis dan berpikir ilmiah; 4) mendorong mahasiswa untuk belajar materi atau konsep baru ketika menyelesaikan masalah; 5) menggabungkan teori dan praktik; 6) memotivasi mahasiswa dan dosen; 7) mahasiswa memperoleh keterampilan manajemen waktu, fokus pengumpulan data, persiapan laporan dan evaluasi; 8) membuka cara untuk belajar sepanjang hayat (Akinoglu dan Tandogen, 2006).

PBL akan lebih efektif jika dipadukan dengan pembelajaran secara tim. Team teaching merupakan metode mengajar beregu yang dapat disajikan dalam 2 teknik yaitu: terintegrasi dan semi terintegrasi. Team teaching teknik terintegrasi adalah teknik team teaching yang menggunakan lebih dari satu orang dosen untuk mengajar secara bersamasama dalam satu kelas. Keunggulan teknik ini adalah meningkatkan kemampuan mahasiswa dalam belajar memecahkan masalah, meningkatkan pengetahuan mahasiswa serta memberikan susana belajar yang baru. Team teaching teknik semi terintegrasi yaitu gabungan dari collaborative team teaching dengan parallel instruction yaitu dua orang dosen yang mengajar secara bersama-sama dan pada saat praktikum seorang dosen membimbing setengah dari jumlah mahasiswa dalam satu kelas. (Shumway, dkk, 2011; Wardani, 2005). Teknik ini memiliki keunggulan adanya perhatian dosen yang lebih kepada mahasiswa sehingga meningkatkan respon dan partisipasi mahasiswa dalam pembelajaran. Pembelajaran yang efektif adalah pembelajaran yang memperhatikan faktor eksternal maupun internal. Faktor internal mahasiswa yang bervariasi seperti kemampuan berpikir kritis dan kemampuan verbal dapat mempengaruhi prestasi belajar. Mengingat pentingnya faktor internal tersebut, maka perlu dipertimbangkan model pembelajaran yang sesuai untuk memfasilitasi faktor internal mahasiswa.

Tujuan dari penelitian ini adalah untuk mengetahui pengaruh model PBL menggunakan team teaching dengan teknik terintegrasi dan semi terintegrasi, kemampuan berpikir kritis dan kemampuan verbal serta interaksinya terhadap prestasi belajar kognitif, afektif, dan psikomotor mahasiswa.

\section{Metode Penelitian}

Penelitian ini dilaksanakan di AAK Nasional Surakarta pada Semester Gasal tahun ajaran 2012/2013

Populasi dalam penelitian ini adalah seluruh mahasiswa AAK Nasional Surakarta Tingkat II Semester III yang sedang mendapat mata kuliah Bakteriologi II sebanyak 47 mahasiswa terbagi dalam 2 kelas, sampel penelitian seluruh anggota populasi yaitu 47 mahasiswa.

Pengambilan sampel dilakukan dengan teknik total sampling. Penelitian eksperimen dilaksanakan dalam design faktorial dengan perlakuan model PBL, team teaching teknik terintegrasi dan semi 
ISSN: 2252-7893, Vol 2, No 12013 (hal 88-99)

http://jurnal.fkip.uns.ac.id/index.php/sains

terintegrasi. Variabel dalam penelitian ini dikelompokkan menjadi 3 yaitu: 1) variabel bebas: team teaching teknik terintegrasi dan semi terintegrasi; 2) variabel moderator: kemampuan berpikir kritis dan kemampuan verbal; 3) variabel terikat: prestasi belajar ranah kognitif, afektif, dan psikomotor (Tabel 2). Instrumen pengambilan data prestasi belajar ranah kognitif, kemampuan berpikir kritis, dan kemampuan verbal menggunakan soal tes, ranah afektif menggunakan lembar observasi dan angket, ranah psikomotor menggunakan lembar observasi dan soal tes.

Tabel 1. Rancangan Penelitian

\begin{tabular}{cccc} 
& & $\begin{array}{c}\text { Model Problem Based } \\
\text { Learning }(\mathrm{A})\end{array}$ \\
\cline { 2 - 4 } & & $\begin{array}{c}\text { Teknik } \\
\text { Terinte } \\
\text { grasi }\end{array}$ & $\begin{array}{c}\text { Teknik } \\
\text { Semi } \\
\text { terintegra } \\
\text { si }\end{array}$ \\
\hline $\begin{array}{c}\text { Kemampuan } \\
\text { berpikir } \\
\text { kritis tinggi } \\
\left(\mathrm{B}_{1}\right)\end{array}$ & $\begin{array}{c}\text { Kemampuan } \\
\text { verbal tinggi }\left(\mathrm{C}_{1}\right)\end{array}$ & $\mathrm{A}_{1} \mathrm{~B}_{1} \mathrm{C}_{1}$ & $\mathrm{~A}_{2} \mathrm{~B}_{1} \mathrm{C}_{1}$ \\
\cline { 2 - 4 } & $\begin{array}{c}\text { Kemampuan } \\
\text { verbal rendah }\left(\mathrm{C}_{2}\right)\end{array}$ & $\mathrm{A}_{1} \mathrm{~B}_{1} \mathrm{C}_{2}$ & $\mathrm{~A}_{2} \mathrm{~B}_{1} \mathrm{C}_{2}$ \\
\hline $\begin{array}{c}\text { Kemampuan } \\
\text { berpikir } \\
\text { kritis rendah } \\
\left(\mathrm{B}_{2}\right)\end{array}$ & $\begin{array}{c}\text { Kemampuan } \\
\text { verbal tinggi }\left(\mathrm{C}_{1}\right)\end{array}$ & $\mathrm{A}_{1} \mathrm{~B}_{2} \mathrm{C}_{1}$ & $\mathrm{~A}_{2} \mathrm{~B}_{2} \mathrm{C}_{1}$ \\
\cline { 2 - 4 } & $\begin{array}{c}\text { Kemampuan } \\
\text { verbal rendah }\left(\mathrm{C}_{2}\right)\end{array}$ & $\mathrm{A}_{1} \mathrm{~B}_{2} \mathrm{C}_{2}$ & $\mathrm{~A}_{2} \mathrm{~B}_{2} \mathrm{C}_{2}$ \\
\hline
\end{tabular}

Instrumen pembelajaran dalam penelitian ini meliputi: Silabus, Rencana Pelaksanaan Pembelajaran (RPP). Instrumen pengambilan data diuji validitas construct dan content oleh ahli dibidang mikrobiologi dan pendidikan.

Data hasil pengujian validitas construct dan content diuji coba pada tempat lain dan dihitung menggunakan teknik korelasi rumus Product-Moment dari Pearson, uji reliabilitas (untuk kognitif dan psikomotor dengan rumus Kuder Richardson dan nilai afektif dengan menggunakan penilaian rumus alpha), uji taraf kesukaran soal, dan uji daya pembeda soal.

Uji prasyarat analisis dilakukan uji normalitas dengan rumus Shapiro-Wilk dan homogenitas. Data prestasi yang diperoleh dianalisis dengan menggunakan uji alternatif Anava.

\section{Hasil Penelitian dan Pembahasan}

Berdasarkan uji normalitas dan homogenitas data untuk prestasi belajar (kognitif, afektif, dan psikomotor) menunjukkan distribusi tidak normal dan tidak homogen, selanjutnya data dianalisa dengan menggunakan uji alternatif ANAVA yaitu Mann-Whitney dan Kruskal Wallis (Tabel 3).

Tabel 2. Uji Alternatif Anava Terhadap Prestasi

\begin{tabular}{|c|c|c|c|c|}
\hline \multirow{2}{*}{ No } & \multirow{2}{*}{ Analisis } & \multicolumn{3}{|c|}{ Nilai Signifikansi } \\
\hline & & Kognitif & Afektif & Psikomotor \\
\hline 1 & Teknik & $0.041^{*}$ & $0.017 *$ & $0.012 *$ \\
\hline 2 & $\begin{array}{l}\text { Kemampuan. } \\
\text { berpikir kritis }\end{array}$ & $0.009^{*}$ & 0.208 & $0.024 *$ \\
\hline 3 & Kemampuan verbal & $0.000 *$ & $0.003^{*}$ & $0.000 *$ \\
\hline 4 & $\begin{array}{l}\text { Teknik*Kemampu } \\
\text { an. berpikir kritis }\end{array}$ & $0.001 *$ & $0.007^{*}$ & $0.001 *$ \\
\hline 5 & $\begin{array}{l}\text { Teknik*Kemampu } \\
\text { an verbal }\end{array}$ & $0.000^{*}$ & $0.000 *$ & $0.000 *$ \\
\hline 6 & $\begin{array}{l}\text { Kemampuan } \\
\text { berpikir } \\
\text { kritis*Kemampuan } \\
\text { verbal }\end{array}$ & $0.000 *$ & $0.007^{*}$ & $0.000 *$ \\
\hline 7 & $\begin{array}{l}\text { Teknik*Kemampu } \\
\text { an berpikir kritis- } \\
\text { Kemampuan verbal }\end{array}$ & $0.000 *$ & $0.001 *$ & $0.000 *$ \\
\hline
\end{tabular}

Ket : *) signifikan pada uji alternatif Anava dengan $\alpha 0,05$

1. Pengaruh model PBL menggunakan team teaching teknik terintegrasi dan semi terintegrasi terhadap prestasi belajar

Berdasarkan hasil uji Mann-Whitney terhadap prestasi didapatkan data bahwa pvalue $<0,05$ pada semua aspek (kognitif, afektif, dan psikomotor) Team teaching teknik terintegrasi memberikan prestasi belajar lebih tinggi yaitu: kognitif dan afektif sebesar 84 , psikomotor sebesar 83 (Tabel 4 dan Gambar 1).

Tabel 3 Hasil Analisis Pengaruh Teknik Pembelajaran terhadap Prestasi Belajar

\begin{tabular}{lccc}
\hline & Kognitif & Afektif & Psikomotor \\
\hline $\begin{array}{l}\text { Teknik } \\
\text { Terintegrasi }\end{array}$ & $79 \mathrm{a}$ & $81 \mathrm{a}$ & $78 \mathrm{a}$ \\
$\begin{array}{l}\text { Teknik Semi } \\
\text { terintegrasi }\end{array}$ & $84 \mathrm{~b}$ & $84 \mathrm{~b}$ & $83 \mathrm{~b}$ \\
\hline $\begin{array}{l}\text { Ket : Angka yang diikuti huruf yang sama tidak berbeda } \\
\text { signifikan pada uji Mann- Whitney dengan } \alpha 0,05\end{array}$
\end{tabular}


ISSN: 2252-7893, Vol 2, No 12013 (hal 88-99)

http://jurnal.fkip.uns.ac.id/index.php/sains

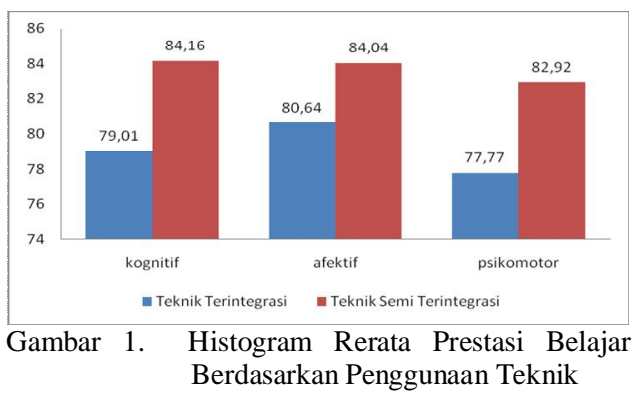

PBL merupakan model pembelajaran yang memiliki karakteristik penyelidikan terhadap masalah yang disajikan. Menurut Bruner (1966 dalam Dahar, 2006) pengetahuan yang didapat melalui penemuan dapat bertahan lama, lebih mudah untuk diingat, meningkatkan penalaran mahasiswa dan kemampuan untuk berpikir secara bebas, memberikan latihan keterampilan kognitif mahasiswa untuk menemukan dan memecahkan masalah tanpa pertolongan orang lain dan memberikan motivasi mahasiswa untuk belajar.

Kegiatan penemuan melalui model PBL menuntut adanya kemampuan berpikir tingkat tinggi, yaitu mengkonstruksi pengetahuan baru kemudian menyusun kembali menjadi konsep kompleks. Pada perwujudan konstruksi dibutuhkan scaffolding, yaitu pemberian bantuan untuk menguasai konsep kepada mahasiswa, bantuan ini dapat berupa dosen, orangtua maupun teman yang lebih mampu. Bantuan diberikan selama tahap awal pembelajaran kemudian mahasiswa mengambil alih tanggung jawab yang semakin besar segera setelah ia dapat melakukannya. Menurut Vygotsky (1978 dalam Dahar, 2006) mahasiswa dapat memperoleh pengetahuan melalui interaksi dengan orang lain yaitu melalui scaffolding. Pada PBL scaffolding lebih banyak diberikan oleh teman sebaya pada diskusi kelompok selama proses pembelajaran, untuk itulah kelompok dibentuk secara heterogen. Dosen memfasilitasi terjadinya interaksi dalam diskusi kelompok, sehingga mahasiswa dapat menguasai konsep dengan bantuan teman dalam kelompoknya.
Team teaching teknik terintegrasi adalah team teaching yang dilakukan oleh 2 dosen secara bersama menyajikan materi dalam kelas dan waktu yang sama, sedangkan team teaching teknik semi terintegrasi adalah variasi team teaching yaitu gabungan dari colaborative team teaching dengan parallel instruction. Pembelajaran dengan team teaching teknik semi terintegrasi memberikan bimbingan lebih efektif dan terarah, kolaborasi dari 2 dosen saat proses apersepsi, motivasi, eksplorasi, dan konfirmasi memperkaya pengetahuan mahasiswa, sedangkan pembimbingan selama praktikum oleh 1 dosen membuat proses penyelidikan lebih terarah dan menghindari kelemahan team teaching yaitu adanya kebingungan pada diri mahasiswa. Hal ini relevan dengan penelitian Syh-Jong-Jang (2006).

Prestasi psikomotor diukur melalui kompetensi mahasiswa saat melakukan praktikum dan penguasaan KPS pada PBL. Perencanaan team teaching dilakukan secara matang dan tersusun baik sehingga ada persamaan persepsi dari 2 dosen dalam membimbing. Team teaching teknik semi terintegrasi memberikan bimbingan lebih efektif karena pada saat praktikum 1 dosen hanya membimbing setengah dari jumlah kelas sehingga membantu mahasiswa berlatih dan menguasai KPS. Hal ini relevan dengan penelitian Keil, et all (2009)

Sintaks model PBL memberikan latihan KPS kepada mahasiswa, pelatihan KPS melibatkan pelatihan sikap ilmiah seperti jujur, teliti, dan kerjasama. Sikap ilmiah tersebut dapat terlihat mulai dari merumuskan masalah sampai kepada menyajikan hasil karya. Team teaching teknik semi terintegrasi memiliki keunggulan dari parallel instruction yaitu meningkatkan respon dan partisipasi mahasiswa dalam belajar. Respon dan partisipasi ini dapat berupa keaktifan dalam praktikum dan bekerjasama dalam kelompok, sehingga prestasi belajar afektif kelompok teknik semi terintegrasi lebih tinggi dibandingkan dengan terintegrasi. 
ISSN: 2252-7893, Vol 2, No 12013 (hal 88-99)

http://jurnal.fkip.uns.ac.id/index.php/sains

2. Pengaruh kemampuan berpikir kritis terhadap prestasi belajar.

Berdasarkan hasil uji Man-Whitney terhadap prestasi didapatkan data bahwa p-value $<0,05$ pada aspek kognitif dan psikomotor, sedangkan aspek afektif memiliki p-value > 0,05. Mahasiswa yang memiliki kemampuan berpikir kritis tinggi memperoleh prestasi lebih tinggi daripada mahasiswa dengan kemampuan berpikir kritis rendah yaitu: kognitif sebesar 86, afektif, dan psikomotor sebesar 83 (Tabel 5 dan Gambar 2).

Tabel 4 Hasil Analisis Pengaruh Kemampuan Berpikir Kritis terhadap Prestasi Belajar

\begin{tabular}{lccc}
\hline & Kognitif & Afektif & Psikomotor \\
\hline $\begin{array}{l}\text { Kemampuan } \\
\text { berpikir kritis tinggi }\end{array}$ & $86 \mathrm{a}$ & $83 \mathrm{a}$ & $83 \mathrm{a}$ \\
$\begin{array}{l}\text { Kemampuan } \\
\text { berpikir kritis } \\
\text { rendah }\end{array}$ & $78 \mathrm{~b}$ & $82 \mathrm{a}$ & $78 \mathrm{~b}$ \\
\hline $\begin{array}{l}\text { Ket : Angka yang diikuti huruf yang sama tidak berbeda } \\
\text { signifikan pada uji Mann-Whitney dengan } \alpha 0,05\end{array}$
\end{tabular}

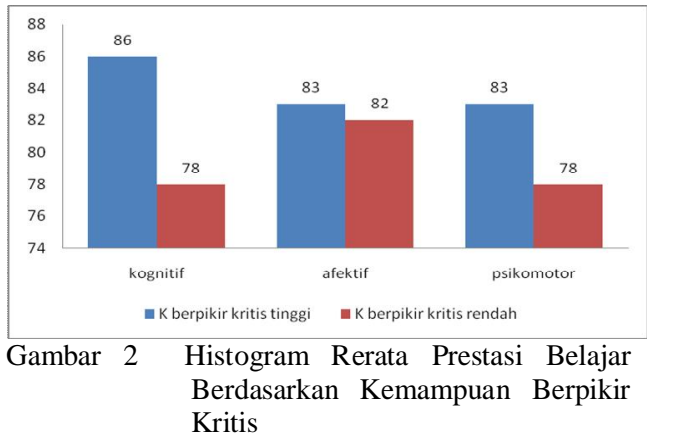

Kemampuan berpikir tingkat tinggi atau High Order Thinking Skill (HOTS). mengandung 3 aspek yaitu: 1) inquiry skills, 2) data processing skills, 3) additional critical thinking. Seseorang dikategorikan kemampuan berpikir tinggi jika keterampilan penemuan, pemrosesan data dan kemampuan berpikir kritisnya tinggi. Berpikir kritis membuat seseorang mampu mempertimbangkan, menghasilkan alasan yang tepat, dan mengambil keputusan berkaitan dengan masalah yang dihadapinya. Melalui berpikir kritis mahasiswa mampu untuk merumuskan masalah, mencari cara pemecahan masalah, melakukan penyelidikan, dan mengevaluasi hasil pemecahan masalah yang telah dilakukan berdasarkan pengetahuan yang telah dimilikinya. Berpikir kritis perlu dikembangkan terusmenerus guna mempersiapkan mahasiswa untuk memasuki dunia kerja (Brookhart, 2010). Prestasi kognitif berhubungan dengan kemampuan berpikir. Mahasiswa yang memiliki HOTS tinggi akan mendapatkan prestasi kognitif tinggi pula. Model PBL memiliki keunggulan mengembangkan kemampuan berpikir kritis. PBL membutuhkan kemampuan berpikir kritis yang digunakan pada setiap kegiatannya yaitu merumuskan masalah dari wacana yang disediakan, menentukan hipotesis, merancang percobaan, melakukan percobaan, menyimpulkan, dan membuat hasil karya. Mahasiswa yang memiliki kemampuan berpikir kritis tinggi akan lebih mudah belajar dengan menggunakan model PBL daripada mahasiswa dengan kemampuan berpikir kritis rendah. Pengembangan berpikir kritis berpengaruh pada peningkatan prestasi kognitif. Menurut Kuswana (2012) peningkatan berpikir kritis sebanding dengan peningkatan IQ seseorang.

Kemampuan berpikir kritis tinggi memberikan pengaruh pada prestasi psikomotor. Prestasi psikomotor berkaitan erat dengan KPS, menurut Gagne (1985 dalam Dahar, 2006) keterampilan psikomotor meliputi keterampilan fisik dan keterampilan intelektual. Model PBL memiliki sintak-sintak yang mampu melatihkan KPS dasar maupun terintegrasi. KPS membutuhkan kemampuan intelektual salah satunya adalah kemampuan berpikir kritis yaitu kemampuan untuk memecahkan masalah, menganalisa argumen, mencari sumber yang dapat dipercaya, membaca tabel atau grafik, mengobservasi, menyimpulkan (Starkey, 2004), sehingga kemampuan berpikir kritis tinggi akan memberikan pengaruh yang positif terhadap prestasi psikomotor.

Menurut Paul (dalam Kuswana, 2012) berpikir kritis berkaitan dengan afektif yaitu kerendahan hati intelektual, keberanian intelektual, empati intelektual, integritas intelektual, dan ingat keadilan, sedangkan prestasi afektif yang diukur 
ISSN: 2252-7893, Vol 2, No 12013 (hal 88-99)

http://jurnal.fkip.uns.ac.id/index.php/sains

pada penelitian ini adalah sikap ilmiah meliputi teliti, jujur dan kerjasama.

3. Pengaruh kemampuan verbal terhadap prestasi belajar.

Hasil uji Mann-Whitney terhadap prestasi didapatkan data bahwa p-value $<0,05$ pada semua aspek (kognitif, afektif, dan psikomotor). Mahasiswa yang memiliki kemampuan verbal tinggi memperoleh prestasi lebih tinggi daripada mahasiswa dengan kemampuan verbal rendah yaitu: kognitif sebesar 87, afektif sebesar 84, dan psikomotor sebesar 85 (Tabel 6 dan Gambar 3).

Tabel 5 Hasil Analisis Pengaruh Kemampuan Verbal terhadap Prestasi Belajar

\begin{tabular}{lccc}
\hline & Kognitif & Afektif & Psikomotor \\
\hline $\begin{array}{l}\text { Kemampuan } \\
\text { verbal tinggi }\end{array}$ & $87 \mathrm{a}$ & $84 \mathrm{a}$ & $85 \mathrm{a}$ \\
$\begin{array}{l}\text { Kemampuan } \\
\text { verbal rendah }\end{array}$ & $79 \mathrm{~b}$ & $80 \mathrm{~b}$ & $76 \mathrm{~b}$ \\
\hline $\begin{array}{l}\text { Ket : Angka yang diikuti huruf yang sama tidak berbeda } \\
\text { signifikan pada uji Mann-Whitney dengan } \alpha 0,05\end{array}$
\end{tabular}

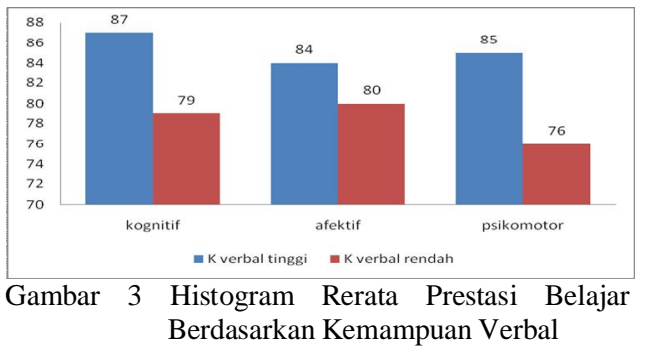

Kemampuan verbal adalah kemampuan menuangkan pengetahuan dalam bentuk bahasa, sehingga dapat mengkomunikasikannya kepada orang lain (Winkel, 1991). Mahasiswa yang memiliki kemampuan verbal tinggi akan mendapatkan prestasi belajar lebih tinggi daripada mahasiswa yang memiliki kemampuan verbal rendah. Hal ini dikuatkan oleh pandangan kognitif Sternberg (1985 dalam Suharman, 2005) bahwa kemampuan kognitif meliputi kemampuan verbal, kemampuan kuantitatif, kemampuan belajar transfer konsep, kemampuan penalaran induktifdeduktif-silogisme, kemampuan ruang, sehingga kemampuan kognitif sebanding dengan kemampuan verbal.
Prestasi psikomotor tinggi didapatkan pada mahasiswa yang memiliki kemampuan verbal tinggi. Prestasi psikomotor berkaitan dengan KPS, kemampuan verbal menunjukkan penguasaan bahasa yang tinggi sehingga terbukti memudahkan kemampuan belajar, mengingat, memecahkan masalah, dan menyimpulkan (Rakhmat, 1996). Model PBL menuntut adanya kemampuan memecahkan masalah melalui metode ilmiah. Kemampuan verbal merupakan modal bagi mahasiswa untuk dapat memecahkan masalah melalui metode ilmiah.

Penilaian afektif berkaitan erat dengan sikap ilmiah. Menurut Gagne (1985 dalam Dahar, 2006) perubahan perilaku diperoleh dari hasil latihan dan pengalaman. Kemampuan verbal tinggi berdampak pada kemampuan memecahkan masalah yang baik melalui metode ilmiah. Penerapan metode ilmiah pada pembelajaran sains akan berdampak pada peningkatan KPS. Peningkatan KPS akan diikuti dengan sikap ilmiah yang baik.

4. Pengaruh interaksi teknik dengan kemampuan berpikir kritis terhadap prestasi balajar.

Berdasarkan hasil uji Kruskal-Wallis terhadap prestasi didapatkan data bahwa p-value < 0,05 pada semua aspek (kognitif, afektif, dan psikomotor). Prestasi belajar tertinggi terdapat pada interaksi team teaching teknik semi terintegrasi dengan kemampuan berpikir kritis tinggi yaitu: kognitif sebesar 90, afektif sebesar 87, dan psikomotor sebesar 88 (Tabel 7 dan Gambar 4).

Tabel 6 Hasil Analisis Pengaruh Interaksi Teknik dengan Kemampuan Berpikir Kritis terhadap Prestasi Belajar

\begin{tabular}{lcccc}
\hline \multicolumn{1}{c}{ Teknik } & $\begin{array}{c}\text { Kemampuan } \\
\text { Berpikir } \\
\text { Kritis }\end{array}$ & Kog & Afek & Psiko \\
\hline Terintegrasi & Tinggi & $83 \mathrm{c}$ & $81 \mathrm{~b}$ & $81 \mathrm{c}$ \\
Semi & Rendah & $72 \mathrm{a}$ & $80 \mathrm{~b}$ & $73 \mathrm{a}$ \\
terintegrasi & Tinggi & $90 \mathrm{~b}$ & $87 \mathrm{c}$ & $88 \mathrm{~b}$ \\
\hline Keterangan : & Angka yang diikuti huruf yang sama tidak \\
& $\begin{array}{l}\text { berbeda signifikan pada uji Mann-Whitney } \\
\text { dengan } \alpha 0,05\end{array}$ & & \\
& & &
\end{tabular}




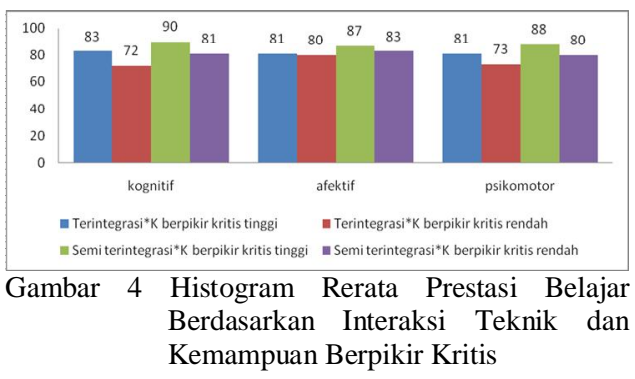

Menurut Winkel (2007) interaksi antara keadaan awal mahasiswa dengan keadaan dosen dapat memberikan efek positif atau negatif. Efek positif terjadi bila kedua interaksi tersebut meningkatkan prestasi belajar, sedangkan efek negatif terjadi bila interaksi tersebut menurunkan prestasi belajar.

Interaksi team teaching teknik teintegrasi dengan kemampuan berpikir kritis memberikan efek positif cukup pada prestasi belajar. Hal ini dikarenakan teknik tersebut menggunakan 2 dosen dari disiplin ilmu yang berbeda secara bersamaan. Penggunaan 2 dosen ini menyebabkan mahasiswa harus beradaptasi dengan keduanya sehingga menimbulkan kebingungan dan akhirnya mempengaruhi prestasi belajar. Kebingungan ini terlihat dari hasil angket maupun wawancara yang dilakukan di akhir penelitian. Keadaan ini sesuai dengan hasil penelitian Yanamandram, Noble (2006), sedangkan interaksi antara team teaching teknik semi terintegrasi dengan kemampuan berpikir kritis memberikan efek positif tinggi pada prestasi belajar. Kolaborasi dosen saat pembelajaran teori dan pengawasan secara mandiri oleh dosen pada saat praktikum memberikan efek positif pada prestasi kognitif baik mahasiswa yang memiliki kemampuan berpikir kritis rendah maupun tinggi.

Prestasi psikomotor berkaitan dengan KPS. Perbedaan pengaruh interaksi team teaching teknik terintegrasi dan semi terintegrasi dengan kemampuan berpikir kritis terhadap prestasi belajar terjadi karena efek yang berbeda dari kedua interaksi tersebut. Team teaching teknik terintegrasi memberikan efek positif cukup sedangkan teknik semi terintegrasi

memberikan efek positif tinggi. Efek positif cukup pada teknik terintegrasi disebabkan perbedaan karakteristik dan kemampuan pedagogi dosen berbeda sehingga mahasiswa mengalami kebingungan dan akhirnya berdampak kurangnya penguasaan KPS.

Sikap ilmiah (teliti, jujur, kerjasama) terbentuk melalui serangkai kegiatan yang melibatkan KPS pada penyelidikan autentik model PBL. Peran dosen sebagai fasilitator dalam penyelidikan autentik sangat diperlukan. Team teaching teknik terintegrasi memungkinkan pengawasan dan pembimbingan lebih intensif daripada teknik semi terintegrasi. Melalui pembimbingan intensif maka peran aktif mahasiswa dapat ditingkatkan sehingga menghasilkan KPS yang tinggi. KPS tinggi akan diikuti dengan sikap ilmiah yang tinggi pula

5. Pengaruh interaksi teknik dengan kemampuan berpikir kritis terhadap prestasi belajar.

Hasil uji Kruskal-Wallis terhadap prestasi didapatkan data bahwa p-value $<0,05$ pada semua aspek. Prestasi belajar mahasiswa yang diberi pembelajaran team teaching teknik semi terintegrasi dengan kemampuan verbal tinggi lebih baik daripada kelompok lain yaitu: kognitif sebesar 90, afektif sebesar 87, dan psikomotor sebesar 88 (Tabel 8 dan Gambar 5).

Tabel 7 Hasil Analisis Pengaruh Interaksi Teknik dengan Kemampuan Verbal terhadap Prestasi Belajar

\begin{tabular}{lcccc}
\hline Teknik & $\begin{array}{c}\text { Kemampuan } \\
\text { Verbal }\end{array}$ & Kog & Afek & Psiko \\
\hline Terintegrasi & Tinggi & $83 \mathrm{c}$ & $81 \mathrm{a}$ & $81 \mathrm{a}$ \\
Semi & Rendah & $75 \mathrm{a}$ & $80 \mathrm{a}$ & $76 \mathrm{a}$ \\
terintegrasi & Tinggi & $90 \mathrm{~d}$ & $87 \mathrm{~b}$ & $88 \mathrm{~b}$ \\
\hline Keterangan : & Anendah & $77 \mathrm{~b}$ & $81 \mathrm{a}$ & $77 \mathrm{a}$ \\
& $\begin{array}{l}\text { berbeda signifikan pada uji Mann-Whitney } \\
\text { dengan } \alpha 0,05\end{array}$ & &
\end{tabular}


ISSN: 2252-7893, Vol 2, No 12013 (hal 88-99)

http://jurnal.fkip.uns.ac.id/index.php/sains

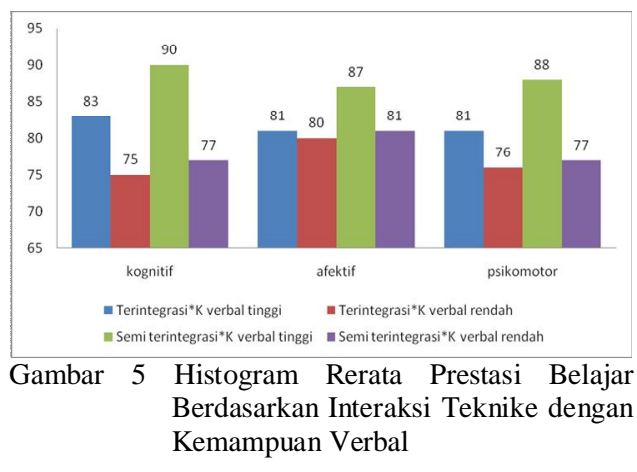

Kemampuan verbal merupakan salah satu komponen intelektual umum Slameto (2003). Kemampuan verbal tinggi akan menghasilkan prestasi kognitif yang tinggi pula. PBL merupakan model pembelajaran yang memberikan pengalaman belajar melalui masalah sosial pada kehidupan nyata. Sintaks dan kegiatan dalam PBL memungkinkan mahasiswa untuk menggunakan kemampuan verbal untuk bekerjasama dalam memahami masalah, mengembangkan hipotesa, mengadakan penyelidikan, menyimpulkan hasil, membuat, dan memamerkan hasil karya (Nur, 2011). Dosen memiliki peran yang tinggi pada PBL, yaitu memberikan bantuan berupa arahan dalam menyelesaikan masalah melalui metode ilmiah, memotivasi mahasiswa untuk terlibat aktif dalam kerjasama kelompok.

Interaksi team teaching teknik semi terintegrasi dengan kemampuan verbal memberikan efek positif tinggi sedangkan teknik terintegrasi dengan kemampuan verbal memberikan efek positif cukupf. Penggunaan teknik semi terintegrasi meningkatkan respon dan partisipasi mahasiswa dalam pembelajaran (Shumway, 2011) sehingga mahasiswa yang diberikan pembelajaran teknik semi terintegrasi dengan kemampuan verbal tinggi memiliki prestasi kognitif lebih tinggi. Kebingungan yang terjadi pada team teaching teknik terintegrasi menyebabkan hambatan pada penguasaan konsep sehingga mahasiswa yang memiliki kemampuan verbal tinggi prestasi belajarnya mengalami penurunan.

Mahasiswa dengan kemampuan verbal tinggi menunjukkan penguasaan bahasa yang tinggi sehingga memudahkan kemampuan belajar, mengingat, memecahkan masalah, dan menyimpulkan (Rakhmat, 1996). Kemampuan memecahkan masalah dilakukan melalui metode ilmiah. Prestasi psikomotor pada mahasiswa yang memiliki kemampuan verbal tinggi dapat diraih secara optimal saat mahasiswa diberikan metode pembelajaran yang dapat memfasilitasi dan mengembangkan kemampuan internalnya. Team teaching teknik semi terintegrasi merupakan teknik yang memfasilitasi kemampuan verbal mahasiswa dengan cara pengawasan dosen secara intensif pada praktikum, dan penggabungan interdisiplin ilmu dosen, sehingga teknik semi terintegrasi yang didukung dengan kemampuan verbal tinggi memberikan pengaruh pada prestasi belajar psikomotor.

Penilaian afektif berkaitan erat dengan sikap ilmiah mahasiswa. Kemampuan verbal tinggi berdampak pada kemampuan memecahkan masalah yang baik dan KPS yang baik pula. KPS yang baik akan diikuti dengan sikap ilmiah yang baik pula. latihan dan pengalaman mahasiswa tidak lepas dari model dan metode yang digunakan. Pengawasan dosen terhadap mahasiswa dengan jumlah sedikit lebih efektif daripada jumlah banyak, sehingga dapat memfasilitasi KPS mahasiswa yang akhirnya berdampak pula pada sikap ilmiah. Oleh karena itu terdapat perbedaan prestasi belajar kemampuan verbal tinggi yang difasilitasi team teaching teknik semi terintegrasi dengan mahasiswa yang difasilitasi team teaching teknik terintegrasi.

6. Pengaruh kemampuan berpikir kritis dengan kemampuan verbal terhadap prestasi belajar.

Hasil uji Kruskal-Wallis terhadap prestasi didapatkan $\mathrm{p}$-value $<0,05$ pada semua aspek. Mahasiswa yang memiliki kemampuan berpikir kritis dan kemampuan verbal tinggi mendapatkan prestasi belajar lebih tinggi pada aspek kognitif dan afektif daripada kelompok lain yaitu: kognitif sebesar 87, afektif sebesar 85 (Tabel 9 dan Gambar 6). 
ISSN: 2252-7893, Vol 2, No 12013 (hal 88-99)

http://jurnal.fkip.uns.ac.id/index.php/sains

Tabel 8 Hasil Analisis Pengaruh Interaksi Kemampuan Berpikir Kritis dengan Kemampuan Verbal terhadap Prestasi Belajar

\begin{tabular}{lcccc}
\hline $\begin{array}{l}\text { Kemampuan } \\
\text { Berpikir } \\
\text { Kritis }\end{array}$ & $\begin{array}{c}\text { Kemampuan } \\
\text { Verbal }\end{array}$ & Kog & Afek & Psiko \\
\hline Tinggi & Tinggi & $87 \mathrm{~b}$ & $85 \mathrm{~b}$ & $84 \mathrm{~b}$ \\
& Rendah & $83 \mathrm{c}$ & $80 \mathrm{~b}$ & $82 \mathrm{~b}$ \\
Rendah & Tinggi & $87 \mathrm{~b}$ & $84 \mathrm{~b}$ & $86 \mathrm{~b}$ \\
& Rendah & $72 \mathrm{a}$ & $82 \mathrm{a}$ & $73 \mathrm{a}$ \\
\hline Keterangan : & Angka yang diikuti huruf yang sama tidak \\
& berbeda signifikan pada uji Mann-Whitney \\
& dengan $\alpha 0,05$ & &
\end{tabular}

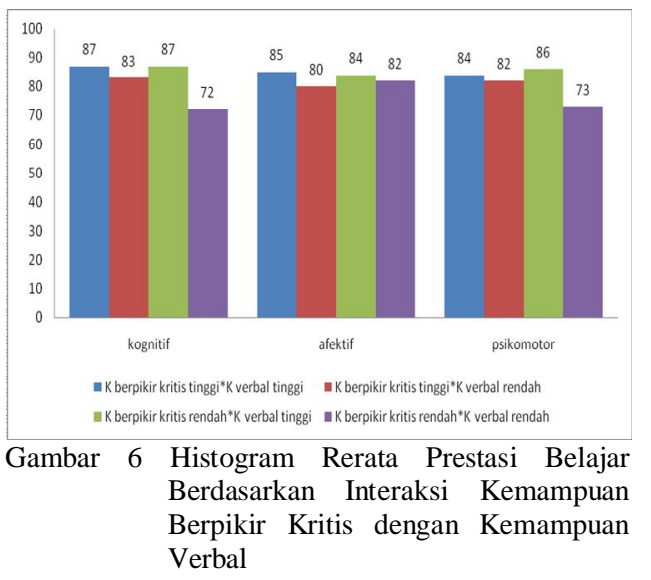

PBL merupakan model efektif untuk mempelajari pengetahuan tertentu, membangun kecakapan sepanjang hayat untuk memecahkan masalah, kerjasama tim, dan komunikasi, mengatur diri sendiri, menggali informasi.

Kemampuan berpikir sangat diperlukan dalam proses pemecahan masalah, sehingga mahasiswa yang memiliki kemampuan berpikir kritis baik akan menjadi pemecah masalah yang baik dan mendapatkan prestasi belajar yang baik pula. Selain berpikir kritis, kemampuan verbal juga dibutuhkan dalam proses pemecahan masalah. Kemampuan verbal memungkinkan mahasiswa untuk mengolah informasi menjadi pengetahuan baru dan menyampaikan pengetahuan yang dimiliki kepada orang lain, hal ini diperlukan dalam kerjasama tim dan mengkomunikasikan pemecahan masalah kepada orang lain.

Menurut Allen et all (1967 dalam Kuswana, 2012) kemampuan berpikir kritis membutuhkan kemampuan verbal.
Kemampuan berpikir kritis tinggi didukung oleh argumentasi verbal tinggi yang dibentuk dari kemampuan verbal tinggi. Hal ini terjadi karena indikator kemampuan verbal tidak berkaitan dengan kemampuan berpikir kritis seperti padanan hubungan, persamaan kata, lawan kata, dan perbendaharaan kata.

Interaksi kemampuan berpikir kritis dan kemampuan verbal memberikan pengaruh pada KPS. PBL meningkatkan peran aktif mahasiswa dalam proses pembelajaran. Keaktifan mahasiswa memberikan pengaruh pada KPSnya. Kemampuan berpikir kritis dan kemampuan verbal masing-masing memberikan konstribusi terhadap KPS, seperti yang telah dibahas sebelumnya bahwa kemampuan berpikir kritis pada penelitian ini memberikan efek positif cukup, sedangkan kemampuan verbal memberikan efek positif tinggi. Efek positif cukup pada mahasiswa yang memiliki kemampuan berpikir kritis tinggi disebabkan karena menggunakan team teaching teknik terintegrasi yang dianggap membingungkan, sedangkan mahasiswa dengan kemampuan berpikir kritis tinggi memiliki frekuensi yang banyak pada kelompok team teaching teknik semi terintegrasi. Hal ini menyebabkan pengaruh interaksi kemampuan berpikir kritis rendah dengan kemampuan verbal tinggi terhadap KPS lebih besar daripada pada interaksi kemampuan berpikir kritis tinggi dan kemampuan verbal rendah sehingga juga berpengaruh pada prestasi psikomotor.

KPS sebanding dengan sikap ilmiah, sehingga KPS yang tinggi akan mengakibatkan sikap ilmiah yang tinggi pula. Sikap ilmiah pada penelitian ini seperti jujur, teliti, dan kerjasama diukur sebagai prestasi afektif.

7. Pengaruh interaksi teknik kemampuan berpikir kritis dan kemampuan verbal terhadap prestasi belajar

Hasil uji Kruskal-Wallis terhadap prestasi didapatkan $\mathrm{p}$-value $<0,05$ pada semua aspek. Mahasiswa yang diberikan team teaching teknik terintegrasi dengan 
ISSN: 2252-7893, Vol 2, No 12013 (hal 88-99)

http://jurnal.fkip.uns.ac.id/index.php/sains

kemampuan berpikir dan verbal tinggi memperoleh prestasi belajar terbaik yaitu: kognitif sebesar 93, afektif sebesar 89, dan psikomotor sebesar 90 (Tabel 10 dan Gambar 7).

Tabel 9 Hasil Analisis Pengaruh Interaksi Teknik, Kemampuan Berpikir Kritis dan Kemampuan Verbal terhadap Prestasi Belajar

\begin{tabular}{llllll}
\hline Teknik & $\begin{array}{l}\text { Kemam } \\
\text { puan } \\
\text { Berpikir } \\
\text { Kritis }\end{array}$ & $\begin{array}{l}\text { Kemam } \\
\text { puan } \\
\text { Verbal }\end{array}$ & Kog & Afek & Psiko \\
\hline $\begin{array}{l}\text { Terinte } \\
\text { grasi }\end{array}$ & Tinggi & Tinggi & $84 \mathrm{~b}$ & $81 \mathrm{ab}$ & $81 \mathrm{ab}$ \\
& Rendah & $81 \mathrm{ab}$ & $82 \mathrm{ab}$ & $90 \mathrm{ab}$ \\
& Rendah & $\begin{array}{l}\text { Tinggi } \\
\text { Rendah }\end{array}$ & $\begin{array}{c}78 \mathrm{a} \\
71 \mathrm{a}\end{array}$ & $\begin{array}{c}81 \mathrm{ab} \\
79 \mathrm{ab}\end{array}$ & $76 \mathrm{a}$ \\
& & Tinggi & $93 \mathrm{~b}$ & $89 \mathrm{c}$ & $90 \mathrm{~b}$ \\
Semi & Tinggi & Rendah & $86 \mathrm{ab}$ & 83 & $86 \mathrm{~b}$ \\
terinte & & Tinggi & $89 \mathrm{~b}$ & $85 \mathrm{~cd}$ & $87 \mathrm{~b}$ \\
grasi & Rendah & Rendah & $73 \mathrm{a}$ & 80 & $73 \mathrm{a}$ \\
& & & & $\mathrm{abc}$ & \\
\hline
\end{tabular}

Keterangan: Angka yang diikuti huruf yang sama tidak berbeda signifikan pada uji Mann-Whitney dengan $\alpha 0,05$

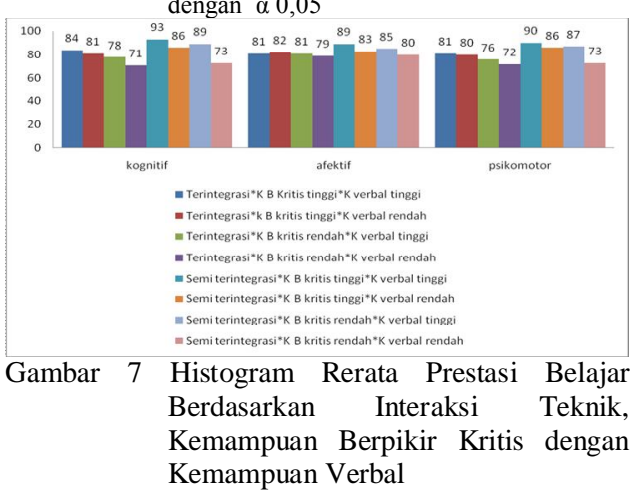

PBL merupakan model pembelajaran yang dikembangkan dari ilmu kedokteran. Masalah yang diangkat pada pembelajaran model PBL adalah masalah pada kehidupan nyata, dengan demikian menantang mahasiswa untuk bekerjasama dalam kelompok dalam menyelesaikan masalah. PBL mempersiapkan mahasiswa untuk berpikir kritis, analisis, dan mencari sumber pembelajaran yang sesuai dalam memecahkan masalah, untuk itu diperlukan kemampuan berpikir kritis, kemampuan verbal, dan dosen yang memiliki kecakapan pedagogi (pengetahuan, membangun interaksi dosen-mahasiswa, interaksi antar mahasiswa, interaksi dosen-mahasiswa dengan informasi) sebagai pendukung
PBL. Fasilitator yang baik dalam PBL membuat mahasiswa aktif terlibat dalam masalah, meningkatkan rasa ingin tahu mahasiswa, memotivasi mahasiswa untuk memecahkan masalah (Amir, 2009). Fasilitator pada team teaching teknik semi terintegrasi lebih optimal daripada teknik terintegrasi sehingga memungkinkan terjadinya scaffolding lebih baik. Menurut Vygotsky (1978 dalam Dahar, 2006) mahasiswa memperoleh pengetahuan melalui interaksi sosial. Kemampuan berpikir kritis, kemampuan verbal, dan penggunaan teknik memberikan penggaruh terhadap prestasi belajar kognitif, afektif, dan psikomotor.

\section{Kesimpulan dan Rekomendasi}

Berdasarkan analisis data dan pembahasan maka dapat ditarik beberapa simpulan antara lain: 1) ada pengaruh model PBL menggunakan team teaching teknik terintegrasi dan semi terintegrasi terhadap prestasi kognitif, afektif, dan psikomotor; 2) ada pengaruh kemampuan berpikir kritis terhadap prestasi kognitif dan psikomotor, 3) ada pengaruh kemampuan verbal terhadap prestasi kognitif, afektif, dan psikomotor, 4) ada pengaruh interaksi teknik dengan kemampuan berpikir kritis terhadap prestasi belajar kognitif, afektif dan psikomotor; 5) ada pengaruh teknik dengan kemampuan verbal terhadap prestasi kognitif, afektif, dan psikomotor; 6) ada pengaruh kemampuan berpikir kritis dan kemampuan verbal terhadap prestasi kognitif, afektif, dan psikomotor; 7) ada pengaruh interaksi teknik, kemampuan berpikir kritis dan kemampuan verbal terhadap prestasi kognitif, afektif, dan psikomotor.

Berdasarkan dari data penelitian, maka disarankan bagi peneliti selanjutnya mengembangkan penelitian dengan teknik team teaching yang lebih bervariasi sehingga diketahui efektifitas teknik team teaching dalam meningkatkan prestasi belajar.

\section{Daftar Pustaka}


ISSN: 2252-7893, Vol 2, No 12013 (hal 88-99)

http://jurnal.fkip.uns.ac.id/index.php/sains

Akinoglu, O and Tandogan, R.O, (2007). The Effect of Problem Based Active Learning in Science Education on Student's Academic Achievement, Attitude and Concept Learning. Eurasia Journal of Mathematics, Science and Technology Education, 3(1), 71-81.

Amir, T.M. (2009). Inovasi Pendidikan Melalui Problem Based Learning. Jakarta: Kencana Prenada Media Group.

Brookhart, S.M. (2010). Asses HigherOrder Thinking Skills in Your Classroom. Virginia: ASCD.

Dahar, R.W. (2006). Teori-Teori Belajar. Jakarta: Erlangga.

Keil, C; Haney, J and Zoffel, J. (2009). Improvement in Student Achievement and Science Process Skills Using Environmental Health Science Problem Based Learning. Electronic Journal of Science Education. 13 (1): 1-18.

Kementrian Kesehatan RI. (2010). Kurikulum Inti Pendidikan Diploma III Analis Kesehatan, Berbasis Kompetensi. Jakarta: Badan Pengembangan dan Pemberdayaan SDM Kesehatan Kementerian Kesehatan Republik Indonesia

Kuswana, W.S. (2012). Taksonomi Kognitif. Bandung: Remaja Rosdakarya.

Nur, M. (2011). Model Pembelajaran Berdasarkan Masalah. Surabaya : Pusat Sains dan Matematika Sekolah UNESA.

Rakhmat, J. (1996). Psikologi Komunikasi. Bandung: Remaja Rosdakarya.
Shumway, L.K. (2011). Co-Teaching Handbook. Salt Lake City: Utah State Office of Education.

Starkey, L. (2004). Critical Thinking Skills Success In 20 Minutes a Day. New York. Learning Express.

Suharman. (2005). Psikologi Kognitif. Surabaya: Srikandi.

Syh-Jong-Jang, (2006). Research on the effect of team teaching upon two secondary school teachers. International Journal Educational Research, 48(2). 177 - 194.

Undang Undang No 36 Tahun 2009 tentang Kesehatan.

Wardani, I. (2005). Team Teaching, Jakarta: Universitas Terbuka.

Weno, I.H. (2008). Strategi Belajar Mengajar Sains Berbasis Kontekstual. Yogyakarta : Inti Media.

Winkel, W.S. (1991). Psikologi Pengajaran. Yogyakarta: Media Abadi, Cet ke-3.

. (2007). Psikologi Pengajaran. Yogyakarta: Media Abadi, Cet ke-9.

Yanamandram, V, Noble, G. (2006). Student Experiences and Perceptions of Team-Teaching in a Large Undergraduate Class. Journal of University Teaching \& Learning Practice. 3(1): 49-66 